\title{
SPATIAL VARIABILITY AND TEMPORAL STABILITY OF WATER STORAGE IN A CULTIVATED TROPICAL SOIL (1)
}

\author{
ANTONIO CARLOS ANDRADE GONÇALVES $\left(2^{*}\right)$; MARCOS ANTONIO TRINTINALHA $\left({ }^{2}\right)$; \\ MARCOS VINICIUS FOLEGATTI ( $\left.{ }^{3}\right)$; ROBERTO REZENDE $\left({ }^{2}\right)$; CÁSSIO ANTONIO TORMENA $\left({ }^{2}\right)$
}

\begin{abstract}
Irrigated agricultural fields usually show variable crop water demand. If water application is done to match this spatially variable demand, the water use efficiency can be substantially improved. Soil water management by irrigation has been one of the most important factors to increase crop yield. To look for the economic viability of the process, the use of several inputs, particularly water, should be done with high efficiency levels. Historically, irrigation uniformity has been evaluated above the soil surface, in which applied water was the only factor to be taken into account. However, the crop will respond to soil water content uniformity, which can differ from the uniformity of water application. To evaluate temporal stability of spatial pattern of soil water storage (SWS), this work was done on a Brazilian clayed soil. Volumetric water content from soil surface to $0,30 \mathrm{~m}$ depth, was measured by TDR in 80 points regularly spaced $(3 \times 3 \mathrm{~m})$ on an experimental area cultivated with bean crop, irrigated by conventional sprinkling. The evaluations were done immediately before and after a water application by irrigation. Experimental semivariograms made from values obtained in the field showed that SWS distribution was spatially structured and strongly stable in time, being regulated mainly by intrinsic factors of the soil. In addition, obtained results showed that water application uniformity did not influence the spatial distribution pattern of SWS in these soil conditions.
\end{abstract}

Key words: irrigation, geostatistics, soil water uniformity, TDR.

\section{RESUMO}

\section{VARIABILIDADE ESPACIAL E ESTABILIDADE TEMPORAL DO ARMAZENAMENTO DE ÁGUA EM SOLO} TROPICAL CULTIVADO

\begin{abstract}
A busca da viabilidade econômica do processo de produção vegetal tem levado produtores à adoção de técnicas de agricultura de precisão. Assim, vem ganhando espaço, em diversas regiões do mundo, a aplicação diferenciada de água, caracterizando a irrigação de precisão. Na irrigação por aspersão, a uniformidade de aplicação de água é base para as análises econômicas do processo de produção. Historicamente, a uniformidade tem sido avaliada sobre a superfície do solo. No entanto, a cultura responderá à uniformidade da umidade do solo, a qual pode diferir da uniformidade de aplicação. Assim, é importante avaliar a uniformidade de distribuição no solo, o que depende de muitas medidas no espaço, repetidas no tempo. O esforço amostral para a realização destas medidas é expressivamente reduzido quando se emprega a técnica da TDR. Para avaliar a estabilidade temporal do padrão espacial do armazenamento de água no solo, este trabalho foi desenvolvido em um solo argiloso do Brasil. A umidade volumétrica do solo na camada de 0 a $0,30 \mathrm{~m}$ de profundidade foi medida por TDR em 80 pontos regularmente espaçados ( $3 \mathrm{~m} \times 3 \mathrm{~m}$ ), em área cultivada com feijão, e irrigada por aspersão convencional. As avaliações foram realizadas imediatamente antes e depois de eventos de chuva ou irrigação. Em semivariogramas experimentais, construídos a partir dos valores medidos, observa-se que no armazenamento de água no solo há estrutura de dependência espacial e foi fortemente estável no tempo, sendo determinado principalmente por fatores intrínsecos ao solo e pouco influenciados pela uniformidade de aplicação.
\end{abstract}

Palavras-chave: irrigação, aspersão, uniformidade, umidade, TDR.

(1) Received for publication in December 20, 2009 and accepted in June 24, 2010.

$\left(^{2}\right)$ Universidade Estadual de Maringá, Maringá (PR). E-mail: acagoncalves@uem.br $\left(^{*}\right)$ Corresponding author; trintinalh@ps5.com.br; rrezende@uem.br; catormena@uem.br.

(3) ESALQ/USP, Caixa Postal 9, 13418-900 Piracicaba (SP). E-mail: mvfolega@esalq.usp.br. 


\section{INTRODUCTION}

Environmental and economic issues have led farmers and technicians to search the optimization of agricultural fertilizers and water use. Site specific management of resources has been done to achieve best economic yield and to minimize losses, which are usually responsible for environmental impacts. In this context, the site specific crop management - SSCM, basis of precision farming, has become important and its application is more frequent. With the aim of combining these objectives, this proposal draws attention from several segments involved in agricultural production, according to FraISSE (2000). In order to achieve such aims, variables involved on production processes have to be treated so as to describe its distribution in space and time. According to Mulla and SCHEPERS (1997), precision farming demands the comprehension of spatial and temporal variability. Thus, the tools which make the spatial description of variables values are useful, according (PIERCE and NOWAK, 1999) and have been widely used. For Bourgault et al. (1997), geostatistics are the most used tools in studies involving spatial variability.

Irrigation was one of the first modifications of natural environment conducted by people. Not only was it of great importance in the past, but it still plays a fundamental role in the world food production. In order to avoid problems which might occur in irrigated areas, management techniques should be developed and applied in order to minimize losses (CHRISTOFIDIS, 2001). Then, the perspective of precision farming shall be extended to water management, usually called Precision Irrigation (QueIROZ et al., 2008). The soil has been usually treated as a homogeneous body regarding SWS, and consequently for the water management in irrigated agriculture. However, the spatial variability of SWS, characteristic of the soil, contributes to variation of the water application efficiency on irrigated agriculture. This causes the necessity of water application to be variable in the irrigated area during the crop season (KING and WALL, 1998). The usual procedures of performance evaluations of the irrigation systems (FrIZZONE, 1992) allow the evaluations of excess and deficit volumes, but they do not inform about the places of occurrence as stated by Evans et al. (1995). The increasing use of fertigation has made the description of spatial distribution of values of applied water depths even more important (CAMP et al., 1998). The knowledge of such spatial distribution allows the establishment of a more efficient resources management. Several authors have presented systems developed for the site-specific management of nutrients and water in center pivot as well as in other mobile irrigation systems (OMARY et al., 1997; MCCANN et al., 1997; CAMP et al., 1998). The site-specific water management cannot only take into account the spatial distribution of applied water. The spatial distribution of the soil water storage (SWS) should also be considered, since according to GREGO and VIEIRA (2005), it has high variability. GONÇALVES et al. (1999) emphasized the importance of adequate sampling for the characterization of this variability. SIQUEIRA et al. (2008) shows the relevance of evaluating the distribution of SWS values in space and time. AlFONSI et al. (1998) highlighted the correlation between SWS variability and water demands of plants.

The evaluation of the temporal stability of the spatial distribution of SWS (SCHMITZ and SOURELL, 2000) demands field measurements of soil moisture in several sampling points, replicated many times (GONÇALVES et al., 1999). In order to supply such sampling effort, the time domain reflectometry - TDR technique can be used in the measurement of soil moisture (Topp et al., 1980). For the dystroferric Red Nitosol (Ultisol) of the studied experimental area, the use of such technique can be improved with the calibration model of TDR established by TrinTINALHA (2000).

The SWS shows variation in space which is not random (RUSSO and BRESLER, 1981). Such variable presents a structural arrangement with a characteristic dimension corresponding to the range of spatial dependence, which means the distance in which there is interdependence of the measured values. According to Ahuja and Nielsen (1990), it results from the parent material characteristics and from the action of soil formation factors. For HAMLETT et al. (1986), the statistical analyses based on the independence of observation have been substituted by spatial analyses which considers the correlations among neighboring observations. These analyses are based on the regionalized variables theory, basis of geostatistics, from works of KRIGE (1966) cited by WEBSTER and OLIVIER (1990) which were followed by works of MATHERON (1971).

This work was aimed at analyzing the spatial and temporal variability of water storage in cultivated soil in a distroferric Red Nitosol (Ultisol) during the drying cycle, after water application by conventional sprinkling irrigation system.

\section{MATERIAL AND METHODS}

The present work was conducted in Maringá, PR, at latitude $23^{\circ} 25^{\prime} \mathrm{S}$ and longitude $51^{0} 57^{\prime} \mathrm{W}$. The average altitude is $540 \mathrm{~m}$ and the predominant climate is Cfa, humid mesothermic with abundant rain in summer and dry winter with annual precipitation average of 1500 $\mathrm{mm}$. The soil is characterized as distroferric Red Nitosol (Ultisol) with clayed texture. The soil surface presents an average slope of $8 \%$. The particle size analysis of 
the soil in the experimental area was carried out with samples obtained from 0 to $0,30 \mathrm{~m}$ depth. The values obtained are: $122.6 \mathrm{gKg}^{-1}$ Sand, $120.6 \mathrm{gKg}^{-1}$ Silt and 756.8 $\mathrm{gKg}^{-1}$ Clay. The soil density was obtained using the volumetric ring method at eighty sampling points, and the average value obtained is $1340 \mathrm{Kgm}^{-3}$.

An area of approximately 0.6 ha was planted with bean crop (Phaseolus vulgaris L.), IPR-Juriti (IAPAR) cultivar. The soil was chiseled at $0,40 \mathrm{~m}$ depth followed by leveling with a harrow. After leveling, furrows were done in soil surface, with $0,45 \mathrm{~m}$ of spacing between them. The fertilization of $250 \mathrm{~kg} \mathrm{ha}^{-1}$ from $02-20-20$ of NPK was carried out using a manual fertilizer distributor. The sowing was performed manually placing the seed above and beside the fertilizer ( 15 seeds per meter). 100 $\mathrm{kg} \mathrm{ha}^{-1}$ of urea was applied in topdressing procedure. During the first two weeks after sowing, irrigations were carried out in the whole area in order to guarantee crop establishment. The sowing was conducted in September allowing the crop development (crop season of about 90 days) in a period with enough precipitation to meet the crop water demand. Thus irrigation was supplementary. An experimental area of $15 \mathrm{~m}$ wide and $48 \mathrm{~m}$ long was defined and irrigated by eight sprinklers with nozzles of 5.6 by $3.2 \mathrm{~mm}$, installed with sprinkler spacing of $12 \times 15$ (4 units) and of $18 \times 15 \mathrm{~m}$ (4 units) in order to promote variable applied water depth, in the experimental area. It was established to study its effects on the SWS variability. Small blocks with $3.0 \mathrm{~m}$ side were selected in the experimental area and in the center of each one a irrigation water catch can was placed. Beside each one, a TDR probe built according to TRINTINALHA (2005) was placed from 0 to $0.30 \mathrm{~m}$. For each water application event, the water applied and the SWS were measured throughout the drying cycle at the 80 sampling points using a TRASE equipment and adopting the calibration model developed by TrintinalHA (2000), which corresponds to a third degree polynomial as suggested by Topp et al. (1980), but with coefficients incorporating the density effect, which is significant for this soil type. In november, after two months of sowing, an irrigation was conducted applying water at an average of 11,1 $\mathrm{mm}$ to the whole area as presented in Table 2. From the estimated values by TDR of the volumetric moisture, soil water storage (SWS) was calculated from 0 to $0,30 \mathrm{~m}$ depth as described by REICHARDT and Timm (2004). SWS were evaluated just before irrigation (Storage before $\mathrm{Sb})$ and six times after the irrigation, named as Storage at time "i" - Si: at S1 (2:00 hours later), S2 (6:30 hours later), S3 (25:15 hours later), S4 (29:00 hours later), S5 (49:30 hours later) and S6 (53:50 hours later).

Measured values of applied water on the soil surface and measured values of SWS were submitted to a statistical analysis (LiBARDI et al., 1996). Initially, descriptive statistics tools and exploratory analysis of the data were used in order to describe the frequency distribution and evaluate the consistency of normality hypotheses or at least the consistency of reasonable symmetry of such distributions. The STATISTICA software was used for these analyses. Next, a spatial exploratory analysis was carried out (ISAAKS and SRIVASTAVA, 1990), aiming to verify if spatial trends or outliers presences occurs at this distributions (HAMLETT et al., 1986). After such verifications, assuming intrinsic stationarity (intrinsic hypothesis) of this distributions, geostatistics analysis of the data set was carried out (GONÇALVES, 1997). Then the experimental semivariograms were built (VIEIRA, 2000), to which the authorized mathematic models were fitted (MCBRATNEY and WeBSTER, 1986) to describe the spatial dependency present in each sampling time. For this, GEOEAS, VARIOWIN and GS+ software were used. After the variographic analysis, the theoretical model fitted to the experimental semivariogram was used to make the kriging interpolation of the SWS values in non sampled points to map this variable in the experimental area. For this mapping, the SURFER software was used. These surfaces allowed the visualization of the distribution of SWS values in space and in time supporting the established hypothesis.

\section{RESULTS AND DISCUSSION}

Statistics of SWS, collected before irrigation and in six moments after it, as well as the irrigation water depth (IWD) values collected in 80 sampling points are shown in table 1 . The average value of applied water was $11.1 \mathrm{~mm}$ as presented in this table. Statistics of SWS values evaluated before irrigation $\mathrm{Sb}$ and six times after, S1 until S6, are presented. As it can be observed in table 1 , where the statistical moments of these variables are presented, the SWS increases after water application and reduces as time passes, characterizing a soil drying process, during the working time. The SWS values reduction is related to water withdrawal of the soil by the crop which was 38 days post-emergence in addition to evaporation and drainage to greater depths. After 29 hours of irrigation (S4), the soil had returned to the same moisture condition before irrigation.

Values of skewness and kurtosis coefficients for irrigation water depth (IWD) suggest that its values are normally distributed. Only one value surpasses the upper limit (UL) for outlier, which does not influence significantly the skewness coefficient, close to zero, neither the kurtosis coefficient, very close to zero, showing the symmetry and the mesokurtic characteristic of the distribution. The proximity between mean and median values corroborates the symmetry of this distribution. On the other hand, the coefficient of 
variation $(\mathrm{CV})$ reveals a strong dispersion of data about the mean, which means low uniformity of irrigation, according to the purpose established in this work.

The values of skewness and kurtosis coefficients for SWS tend to show symmetric distributions, which is corroborated by the proximity of mean and median values. The lack of outliers in the distributions confirms this symmetry, expressed by low values of $\mathrm{CV}$, less than those found by SIQUEIRA et al. (2008). These values show that the irregular water application on the surface slightly affected the variability of SWS values in the studied conditions.

Spatial distributions of irrigation water depth (IWD) and of soil water storage (SWS) at $0.30 \mathrm{~m}$ depth in the soil, measured in the 80 sampling points, before application of water (Sb), immediately after (S1), and in the last evaluation moment (S6), are showed in figure 1. The result shows that a spatial pattern of SWS before irrigation ( $\mathrm{Sb}$ ) could be characterized by a CV of $11.76 \%$, that expresses a littlevariation of thesevalues. This spatial pattern remains practically the same after irrigation (S1 and S6) since water application by irrigation, although with low uniformity (CV of $43.74 \%$ ), did not determine a new spatial distribution pattern of SWS.

Although in some points there is a relatively high storage variation between before irrigation $(\mathrm{Sb})$ and the first reading after irrigation (S1) resulting from higher values of applied water (Figure 1), the spatial pattern of this distributions is only slightly altered. After water application, the low uniformity of such application imposed a greater variability in SWS values. In table 1 it is noticeable that as the soil dries, the CV values of the SWS distributions increase, varying about $12 \%$ immediately after irrigation and even more than $14 \%$ in the sixth reading (S6). These values are higher than the ones obtained before irrigation ( $\mathrm{CV}$ of $11.76 \%$ ) even though it is possible to notice that from the fourth reading (S4) the soil is in average drier than before irrigation. This means that the non-uniform irrigation imposed a greater variability on SWS values, which is persistent in

Table 1. Statistics of applied irrigation water depth (IWD) and SWS values expressed in mm, measured before irrigation (Sb) and after it (Si) throughout time

\begin{tabular}{|c|c|c|c|c|c|c|c|c|}
\hline \multirow[b]{2}{*}{ Moments } & \multicolumn{8}{|c|}{ Variables $(\mathrm{mm})$} \\
\hline & IWD & $\mathrm{Sb}$ & S1 & $\mathrm{S} 2$ & S3 & S4 & S5 & S6 \\
\hline Number & 80 & 80 & 80 & 80 & 80 & 80 & 80 & 80 \\
\hline Mean & 11.10 & 119.23 & 126.12 & 122.73 & 120.40 & 118.53 & 113.41 & 110.80 \\
\hline Median & 11.16 & 120.33 & 126.96 & 123.45 & 121.13 & 119.53 & 113.88 & 112.35 \\
\hline Minimum & 1.38 & 86.31 & 91.25 & 89.63 & 88.53 & 87.42 & 78.84 & 76.47 \\
\hline Maximum & 25.69 & 142.93 & 152.35 & 148.35 & 146.85 & 146.85 & 144.32 & 143.40 \\
\hline L. quartile & 7.42 & 109.66 & 115.23 & 114.10 & 111.46 & 109.65 & 104.27 & 100.09 \\
\hline U. quartile & 14.14 & 128.73 & 139.51 & 133.54 & 131.93 & 129.59 & 124.21 & 121.71 \\
\hline Variance & 23.58 & 196.57 & 238.49 & 225.45 & 223.83 & 227.59 & 243.17 & 244.41 \\
\hline S. deviation & 4.86 & 14.02 & 15.44 & 15.01 & 14.96 & 15.09 & 15.59 & 15.63 \\
\hline Skewness & 0.35 & -0.33 & -0.29 & -0.31 & -0.24 & -0.22 & -0.20 & -0.19 \\
\hline Kurtosis & 0.02 & -0.56 & -0.80 & -0.83 & -0.86 & -0.84 & -0.68 & -0.72 \\
\hline Range & 6.73 & 19.08 & 24.29 & 19.44 & 20.48 & 19.95 & 19.94 & 21.62 \\
\hline U.L.-outliers & 24.23 & 157.34 & 175.94 & 162.69 & 162.65 & 159.51 & 154.12 & 154.15 \\
\hline L.L.-outliers & -2.68 & 81.04 & 78.80 & 84.94 & 80.74 & 79.72 & 74.36 & 67.66 \\
\hline $\mathrm{CV}$ & 43.74 & 11.76 & 12.25 & 12.23 & 12.43 & 12.73 & 13.75 & 14.11 \\
\hline
\end{tabular}

Table 2. Pearson linear correlation coefficients (r) for irrigation water depth (IWD) and soil water storage (SWS), before irrigation $\mathrm{(Sb)}$ and after irrigation (Si)

\begin{tabular}{llllllll}
\hline & \multicolumn{7}{c}{ Variables } \\
\cline { 2 - 7 } & IWD & Sb & S1 & S2 & S3 & S4 & S5 \\
\hline IWD & 1.000 & & & & & & \\
Sb & 0.118 & 1.000 & & & & & \\
S1 & 0.479 & 0.874 & 1.000 & & & & \\
S2 & 0.463 & 0.890 & 0.992 & 1.000 & & & \\
S3 & 0.451 & 0.893 & 0.989 & 0.998 & 1.000 & & \\
S4 & 0.445 & 0.890 & 0.982 & 0.994 & 0.996 & 1.000 & \\
S5 & 0.448 & 0.891 & 0.977 & 0.987 & 0.991 & 0.993 & 1.000 \\
S6 & 0.445 & 0.889 & 0.973 & 0.983 & 0.986 & 0.990 & 0.997 \\
\hline
\end{tabular}


time. However, it can be seen (Figure 1) that, although this may happen, the temporal persistency of the spatial pattern determined by the soil is much more evident.

In order to evaluate this temporal stability of SWS spatial pattern, the graphic presented in figure 2 was built, in which SWS values after irrigation (S1, S4 and S6) are plotted in relation to storage before irrigation (Sb).

The S1 values on figure 2 are placed above the straight line 1:1 once the soil is, in average, moister than before irrigation, at this moment. For S6 values, it is noticeable that the soil is, in average, drier than before irrigation, which causes the points to be mainly below the straight line 1:1. For A4 values, when soil moisture is in average more similar to what there was before irrigation, the points are distributed around the straight line 1:1. The CV's values presented on table 1 show that variability of SWS values at these three sampling moments after irrigation remain with little modifications (CV between 12 to 14\%). This fact can be

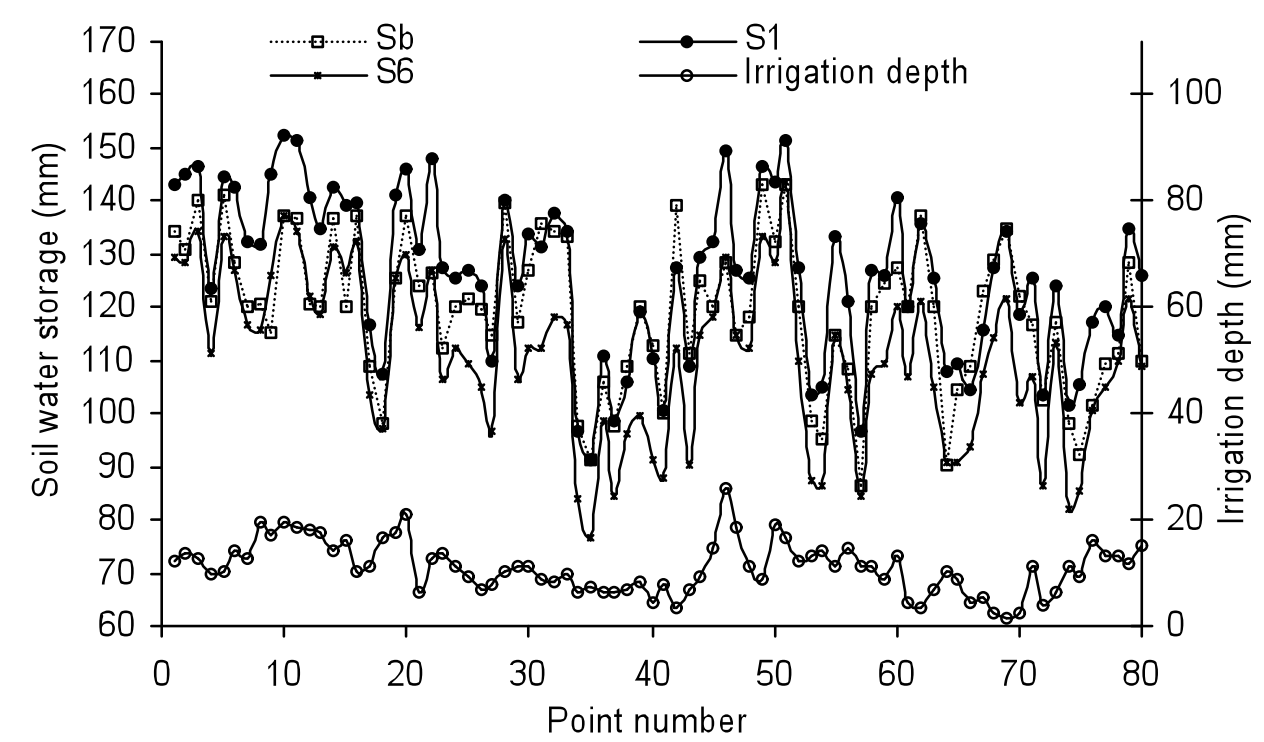

Figure 1. Irrigation water depth (IWD) and soil water storage (SWS), before water application (Sb), in the first moment (S1) and in the last moment of reading (S6).

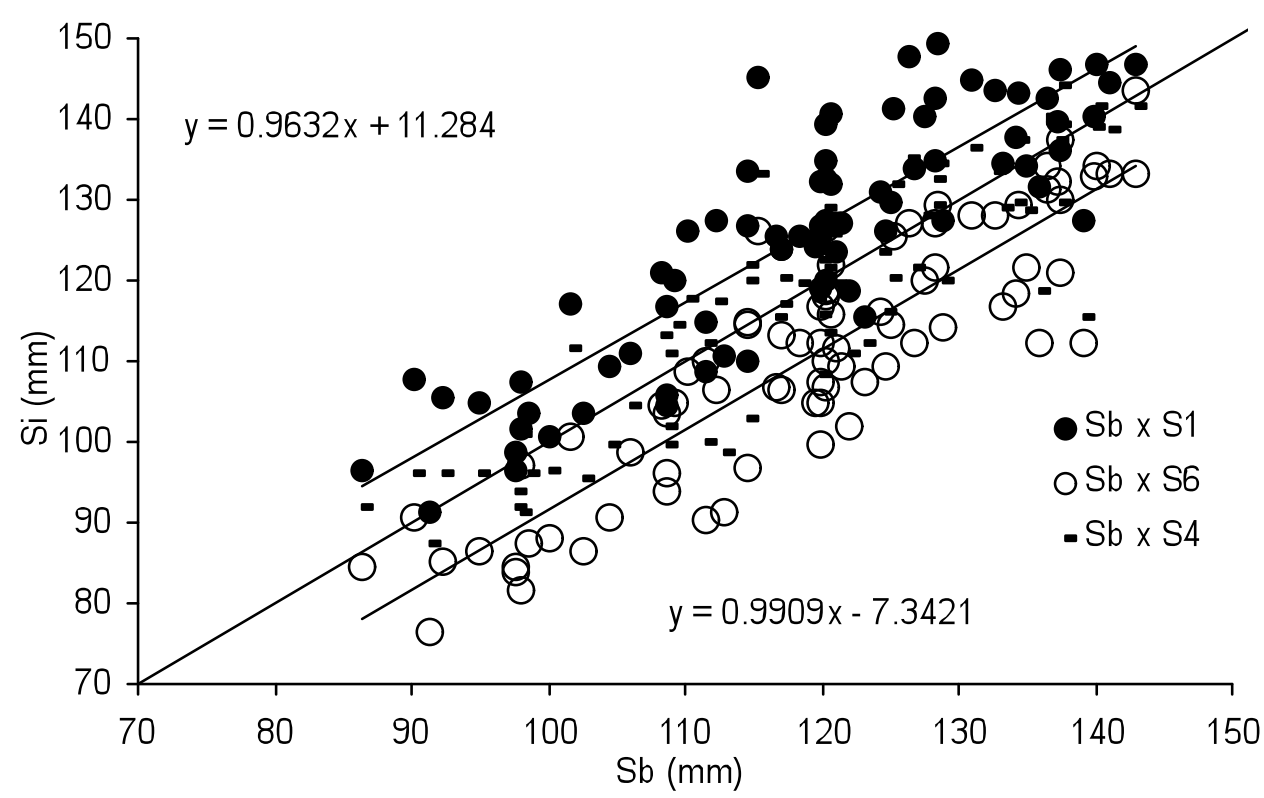

Figure 2. Soil water storage (SWS) values in three moments after irrigation (S1, S4 and S6), in relation to storage before irrigation (Sb). 
observed on figure 2 in which the points on the graph present similar dispersion around the fitted linear model to each series values. The models fitted to S1 values and $\mathrm{S} 6$ are practically parallel to the straight line 1:1, which means that their angular coefficients (slope) are very close to the unit. At figure 2 these slopes values are showed, 0.96 and 0.99 , respectively, for S1 and S6. The parallelism of two fitted model, in relation to 1:1 line, and between them, shows that the spatial distribution of SWS values remains practically the same, although the change of relative position in relation to the 1:1 line expresses the change of soil water content between these sampling moments. We can also highlight the fact that slope value of fitted model is smaller for the first moment after irrigation. However, it approaches the unit as the soil dries, revealing the reestablishment of the spatial pattern of SWS. This fact suggests that this spatial pattern is an intrinsic characteristic of this soil.

A more detailed analysis of the Pearson linear correlation coefficient (r) can be conducted from values presented in table 2. In this table, the matrix of the $r$ values for SWS values before irrigation $(\mathrm{Sb})$ and the values measured after ( $\mathrm{Si}$ ) as well as the irrigation water depth values (IWD) are shown. It is possible to verify that $r$ values between $S b$ and $S i$ vary slightly, although they present a slight increase trend between the moment referring to S1 and S3. Then, the soil reaches lower levels between $\mathrm{S} 4$ and $\mathrm{S} 6$ than the ones observed before irrigation $(\mathrm{Sb})$ and the $\mathrm{r}$ values decrease.

The $r$ values between the series in the order of $\mathrm{Si}$ and $\mathrm{Si}+\mathrm{j}$, shows a slight decrease trend along the time, showing little modification of SWS dispersion between adjacent series. On the other hand, the $r$ values presented at the last line of this table shows that these values increase along the time. That means that as the soil dries; the SWS spatial distribution recovers its intrinsic pattern. It is also possible to highlight the increase of $r$ values between adjacent moments along the time, revealing that the distributions of storage values become even more similar to each other.

The correlation between $\mathrm{Sb}$ and $\mathrm{Si}$ values and irrigation water depth (IWD) revealed that the distribution of such values slightly affected the distribution of SWS and that this effect decreases with time. Thus, it is possible to notice that, in a general way, the actual distribution of SWS in these conditions is more efficient to describe the future pattern of SWS than the distribution of applied water. After the descriptive and exploratory statistical analysis of SWS values, we evaluated if the values distribution of this variable is structured in space. For this, experimental semivariograms were built from values measured in the field before water application and in six moments after it. The experimental semivariograms for SWS values before water application $(\mathrm{Sb})$ and in the six moments after application $(\mathrm{Si})$ are presented in figure 3 .

The exponential model fitted to the experimental semivariogram obtained for $\mathrm{S} 1$ is presented (Figure 3). Theexperimental semivariograms for the values referring to $\mathrm{S} 2 ; . . . ; \mathrm{S} 6$ series are also presented. It is possible to verify that the model fitted for S1 describes adequately the other semivariograms once the semivariance values obtained in each lag are practically coincident.

The water application promoted some alteration in the semivariance values making them higher than those obtained before water application. This effect can be observed in figure 3 . As presented in table 1 , the variance of the values obtained in $\mathrm{S} 1$ is higher than the

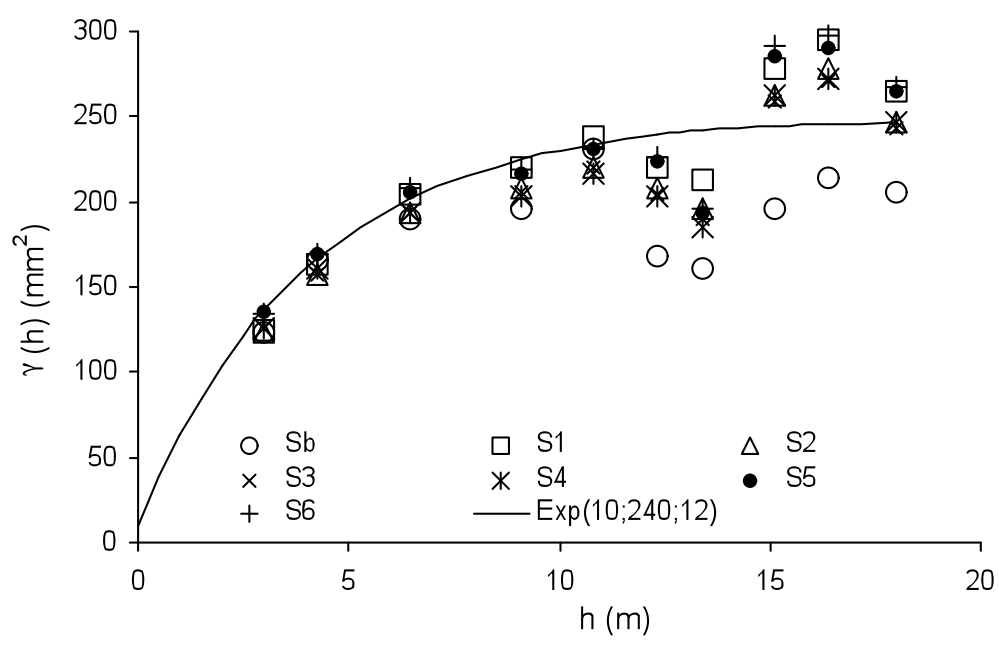

Figure 3. Experimental semivariograms for soil water storage (SWS) before water application (Sb) and after this (S1, S2;...; S6), and the model fitted for S1. 
one obtained for $\mathrm{Sb}$, showing that water application contributed to increase the coefficient of variation of SWS values due to the low uniformity of water application in the whole area. The fitted exponential model has a nugget effect equals to $10 \mathrm{~mm}^{2}$, sill of 240 $\mathrm{mm}^{2}$ and range of 12 meters. As it can be observed in table 1, such sill values practically coincide with the data variance of S1, which corroborates the intrinsic hypothesis of the process initially accepted. The experimental semivariograms, allied to the fitted model, allow the knowledge of a strong spatial dependency for the variable in all evaluated moments.

SWS values distribution can be mapped by kriging interpolation from measured values using the fitted semivariograms models for data series. For the data series considered in this event, the exponential model fitted to S1 series was used in the interpolation for the other series, due to the strong similarity among the experimental semivariograms, as described. The interpolation of the IWD water values was not carried out using kriging once the variation of this variable in space occurred due to pre-established reasons related to the space between sprinklers and other characteristics of such irrigation. Because of this, it was decided not to characterize such a process as a random function, and consequently a geostatistic approach was not proceeded.

Spatial distribution of soil water storage (SWS) values in the experimental area before water application is presented in figure 4. Although an expressive variability of values in space can be observed, the intrinsic stationarity of the process accepted a priori, can be corroborated by a spatial distribution which is not characterized by any trend that can show a systematic variation.
Considering that the water application was carried out as previously described, it was tried to visualize the distribution of SWS values after irrigation. In figure 5, this variable values for the moment $S 1$ are presented.

It is possible to verify that the water application slightly modifies the spatial distribution of SWS. Naturally, the regions which received higher amounts of water ( $X$ coordinate about $30 \mathrm{~m}$ ) still present slightly higher storage values observed before water application. On the other hand, points which received water a bit above the unit presented slightly lower storage than the one measured before irrigation. Thus, it is possible to observe that the spatial distributions of the values presented in figures 4,5 and 6 shows that such distribution depends more on intrinsic factors of the soil than on applied water distribution.

This verification should be in great extension also due to the fact that the water available for the plants in this soil, between field capacity and permanent wilting point, is considerably lower than SWS when the soil is in permanent wilting point. Because of this, the water depth necessary to replace the soil moisture in the range corresponding to the tensiometer operation $(15 \mathrm{~mm})$ corresponds to a low percentage of the average SWS before irrigation. Then, such application, even if carried out with very high uniformity (or very low), has only a slight influence on the SWS spatial distribution.

The last series of SWS values measured during this event (S6) was used for the surface construction presented in Figure 6. It is possible to notice that the spatial distribution pattern remained similar to the one obtained in S1 presenting surface movement to the bottom due to the soil drying process.

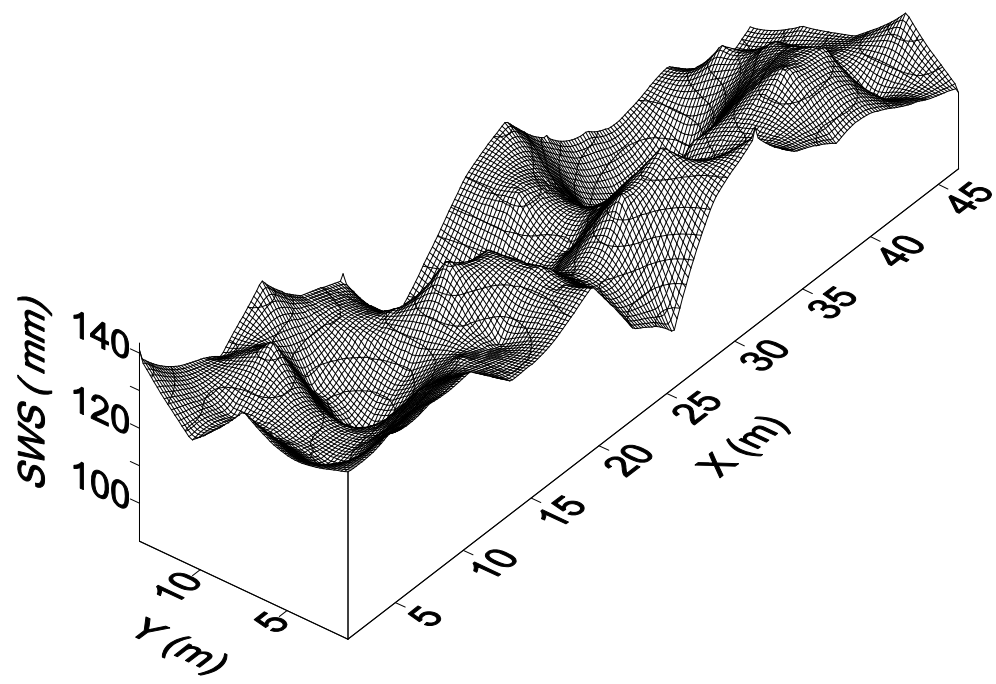

Figure 4. Spatial distribution of soil water storage (SWS) values in the experimental area before water application (Sb). 


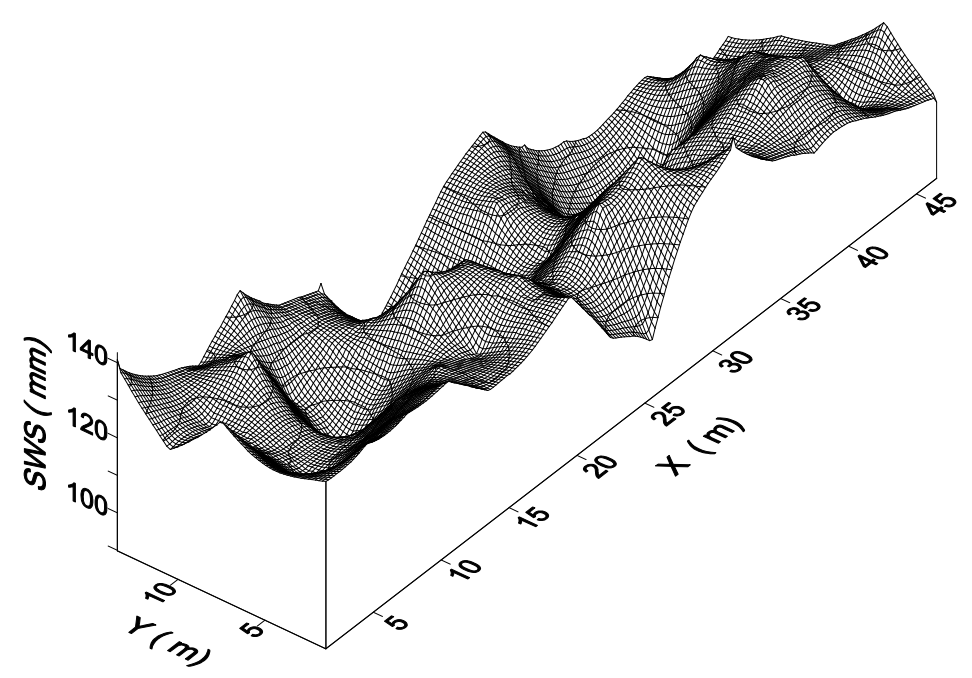

Figure 5. Spatial distribution of soil water storage (SWS) values in the experimental area after water application (S1).

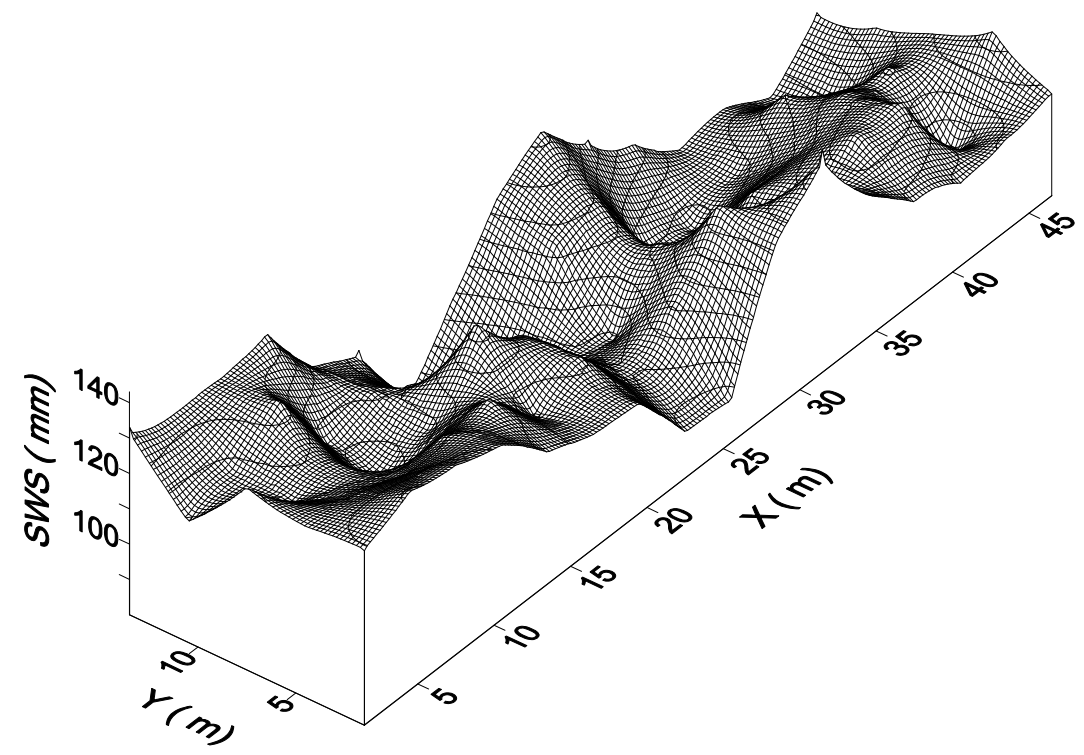

Figure 6. Spatial distribution of soil water storage (SWS) values of the experimental area after water application (S6).

The comparison between SWS values in the moment of the last measurement carried out during this event (S6) with the values before irrigation $(\mathrm{Sb})$ reveals that the pre-existing spatial distribution remained after the drying cycle. During this process, the crop cover, as previously discussed, may have influenced in a way that small differences observed in spatial pattern were obtained.

Due to the results obtained with water application via low uniformity irrigation the expectation is that, in events with high application uniformity (rain), the results obtained show, with more evidence, that SWS pattern depends fundamentally on soil's intrinsic factors than on the water application pattern.

\section{CONCLUSION}

In the conditions studied, the crop cover did not promote substantial alterations in the space-temporal distribution of the SWS values. This means that soil's intrinsic factors were more effective in the definition of SWS spatial pattern, which presented high temporal stability during the analyzed event. 


\section{REFERENCES}

AHUJA, L.R.; NIELSEN, D.R. Field soil-water relations. In: Irrigation of agricultural crops. Madison, 1990. Chap.7, p.143189. (Agronomy Monograph, 30)

ALFONSI, R.R.; BRUNINI, O.; CAMARGO, M.B.P.; PEZZOPANE, J.R.M. Disponibilidade hídrica no solo para a cultura do milho no Estado de São Paulo, em função de épocas de semeadura e cultivares. Bragantia, v.57, p.127-133, 1998.

BOURGAULT, G.; JOURNEL, A.G.; RHOADES, J.D.; CORWIN, D.L.; LESCH, S.M. Geostatistical analysis of a soil salinity data set. Advances in Agronomy, v.58, p.241-292, 1997.

CAMP, C.R.; SADLER, E.J.; EVANS, D.E.; USREY, L.J. OMARY, M. Modified center pivot system for precision management of water and nutrients. Applied Engineering in Agriculture, v.14, p.23-31. 1998.

CHRISTOFIDIS, D. Os recursos hídricos e a prática da irrigação no Brasil e no mundo. ITEM - irrigação e tecnologia moderna, v.49, p.8-13, 2001.

EVANS, R.G.; HAN, S.; KROEGER, M.W. Spatial distribution and uniformity evaluations for chemigation with center pivots. Transactions of the ASAE, v.38, p.85-92, 1995.

FRAISSE, C.W. Agricultura de precisão: oportunidades e Desafios. Columbia, Missouri: USDA-Agricultural Research Service, 2000. Disponível em: http://mpac.missouri.edu/ pubs.

FRIZZONE, J.A. Irrigação por aspersão: uniformidade e eficiência. Piracicaba: ESALQ, 1992. 53p. (Série Didática, 003 - DER)

SIQUEIRA, G.M.; VIEIRA, S.R.; CAMARGO, M.B.P. Variabilidade espacial do armazenamento e perda média diária de água pelo solo no sistema de semeadura direta em Campinas, SP. Bragantia, v.67, p.213-223, 2008.

GONÇALVES, A.C.A.; FOLEGATTI, M.V.; SILVA, A.P. Estabilidade temporal da distribuição espacial da umidade do solo em área irrigada por pivô central. Revista Brasileira de Ciência do Solo, v.23, p.155-164, 1999.

GONÇALVES, A.C.A. Variabilidade espacial de propriedades físicas do solo para fins de manejo de irrigação. 1997. 118f. Tese (Doutorado) - Escola superior de agricultura "Luiz de Queiroz" / USP, Piracicaba-SP.

GREGO, C.R.; VIEIRA, S.R. Variabilidade espacial de propriedades físicas do solo em uma parcela experimental. Revista Brasileira de Ciência do Solo, v.29, p.169-177, 2005.

HAMLETT, J. M.; HORTON, R.; CRESSIE, N. A. C. Resistant and exploratory techniques for use in semivariogram analyses. Soil Science Society of America Journal, v.50, p.868-875, 1986.
ISAAKS, E.H.; SRIVASTAVA, R.M. An Introduction to Applied Geostatistics. New York: Oxford University Press, $1989561 \mathrm{p}$.

KING, B.A.; WALL, R.W. Supervisory control and data acquisition system for site-specific center pivot irrigation. Applied Engineering in Agriculture, v.14, p.135-144. 1998.

KRIGE, D.G. Two-dimensional weighted moving average trend surfaces for ore-evaluation. Journal of the South African Institute of Mining and Metallurgy, v.66, p.13-38, 1966.

LIBARDI, P.L.; MANFRON, P.A.; MORAES, S.O.; TUON, R.L. Variabilidade da umidade gravimétrica de um solo hidromórfico. Revista Brasileira de Ciência do Solo, v.20, p.1-12, 1996.

MATHERON, G. The theory of regionalized variables and its applications. Paris: Ecole Nationale Supe Rieuredes Mines, 1971.211p. (Cahiers du Centre de Morphologie Mathématique de Fointanebleau, n.5)

McBRATNEY, A.B.; WEBSTER, R. Choosing functions for semi-variograms of soil properties and fitting them to sampling estimates. Journal of Soil Science, v.37, p.617-639, 1986.

McCANN, I.R.; KING, B.A.; STARK, J.C. Variable rate water and chemical application for continuous-move sprinkler irrigation systems. Applied Engineering in Agriculture, v.13, p.609-615. 1997.

MULLA, D.J., SCHEPERS, J.S. Key processes and properties for site-specific management. In: PIERCE, F.J., SADLER, E.J. (Ed.). The state of site-specific management for agriculture. Madison, WI: ASA, CSSA, and SSSA, 1997. 18p.

OMARY, M.; CAMP, C.R.; SADLER, E.J. Center pivot system modification to provide variable water application depths. Applied Engineering in Agriculture, v.13, p.235-239, 1997.

PIERCE, J.F., NOWAK, P. Aspects of precision agriculture. Advances in Agronomy, v.67, p.1-85. 1999.

QUEIROZ, T.M.; BOTREL, T.A.; FRIZZONE, J.A. Desenvolvimento de software e hardware para irrigação de precisão usando pivô central. Engenharia Agrícola, v.28, p. 44-54. 2008.

REICHARDT, K.; TIMM, L.C. Solo, planta e atmosfera: conceitos, processos e aplicações. Barueri: Manole, 2004. $478 \mathrm{p}$.

RUSSO, D.; BRESLER, E. Soil hidraulic properties as stochastic processes: I. An analysis of field spatial variability . Soil Science Society of America Journal. v.45, p. 682-687. 1981.

SCHMITZ, M.; SOURELL, H. Variability in soil moisture measurements. Irrigation Science, v.19, p.147-151, 2000. 
TOPP, G.C.; DAVIS, J.L.; ANNAN, A.P. Electromagnetic determination of soil water content: measurements in coaxial transmission lines. Water Resources Research, v.16, p.574582, 1980.

TRINTINALHA, M.A. Avaliação da técnica de reflectometria no domínio do tempo (tdr) na determinação de umidade em Nitossolo Vermelho Eutroférrico. 2000. 67f. Dissertação (Mestrado) - Universidade Estadual de Maringá, Maringá (PR).

TRINTINALHA, M.A. Distribuição espacial e estabilidade temporal do armazenamento de água em um Nitossolo, medido utilizando-se a técnica de tdr. 2005. 126f. Tese (Doutorado) - Universidade Estadual de Maringá. MaringáPR.

VIEIRA, S.R. Geoestatística em estudos de variabilidade espacial do solo. In: NOVAIS, R.F.; ALVAREZ, V.H.; SCHAEFER, G.R. (Ed.). Tópicos em Ciência do Solo. Viçosa: Sociedade Brasileira de Ciência do Solo, v.1, p.1-54, 2000.

WEBSTER, R.; OLIVIER, M.A. Statistical methods in soil and land resource survey. Oxford: Oxford University Press, 1990. $316 \mathrm{p}$. 